\title{
Search for Candidate Genes Causing the Excessive Ca Accumulation in Roots of Tipburn-Damaged Lisianthus (Eustoma grandiflorum) Cultivars
}

\author{
Takanori Kuronuma * and Hitoshi Watanabe * \\ Center for Environment, Health and Field Sciences, Chiba University, 6-2-1 Kashiwa-no-ha, Kashiwa-city, \\ Chiba 277-0882, Japan \\ * Correspondence: t.kuronuma@chiba-u.jp (T.K.); hwatanabe@faculty.chiba-u.jp (H.W.)
}

check for updates

Citation: Kuronuma, T.; Watanabe, H. Search for Candidate Genes Causing the Excessive Ca Accumulation in Roots of Tipburn-Damaged Lisianthus (Eustoma grandiflorum) Cultivars. Agriculture 2021, 11, 254. https://doi.org/10.3390/ agriculture11030254

Academic Editor: Jaime Prohens

Received: 21 February 2021

Accepted: 13 March 2021

Published: 17 March 2021

Publisher's Note: MDPI stays neutral with regard to jurisdictional claims in published maps and institutional affiliations.

\begin{abstract}
Occurrence of tipburn is a severe problem in the production of lisianthus cultivars. Previous studies have shown excessive Ca accumulation in the roots of tipburn-damaged cultivars, where the distribution of $\mathrm{Ca}$ to the tips of the top leaves is inhibited. However, few studies have investigated the association between $\mathrm{Ca}$ accumulation and gene expression in horticultural crops. To provide a list of candidate target genes that might be causing the excessive $\mathrm{Ca}$ accumulation in roots, we focused $\mathrm{Ca}^{2+}$ transporter and pectin methylesterase (PME) genes and RNA-seq of upper leaves and roots in tipburn-occurrence cultivar ("Voyage peach": VP) and non-occurrence cultivar ("Umi honoka": UH) was conducted. In both the upper leaves and roots of VP, genes encoding the glutamate receptors (GLRs), cation/ $\mathrm{Ca}^{2+}$ exchangers 4 (CCX4), $\mathrm{Na}^{+} / \mathrm{Ca}^{2+}$ exchanger-like protein (NCL), and PMEs were upregulated, and a gene encoding the cyclic nucleotide-gated ion channel 9 (CNGC9) was downregulated. In contrast, genes encoding the vacuolar cation/proton exchanger 5 (CAX5), calcium-transporting ATPase 1 and 12 (ACA1 and ACA12) showed differential expression in each organ. Among them, only $C A X 5$ was upregulated and $A C A 12$ was downregulated in the roots of VP. Based on these results, we suggested that $C A X 5$ and $A C A 12$ are the candidate genes causing the excessive $\mathrm{Ca}$ accumulation in the roots of tipburn-occurrence lisianthus cultivars. Future studies should investigate the temporal changes in gene expression using quantitative PCR and conduct functional analysis of candidate genes in tipburn-damaged lisianthus cultivars.
\end{abstract}

Keywords: Ca deficiency; RNA-seq; Ca accumulation; Ca channel; Ca pump; Ca antiporter; pectin methylesterase

\section{Introduction}

Calcium $(\mathrm{Ca})$ is an essential plant macronutrient and plays a vital role in plant growth. It acts as a counter cation in storage organelles and a crucial intracellular second messenger that provides protection against stresses [1]. The concentration of $\mathrm{Ca}^{2+}$ in the cytosol (cytosol $\left.\left[\mathrm{Ca}^{2+}\right]\right)$ is tightly regulated by three classes of transporters: Ca channels, $\mathrm{Ca}^{2+}$-ATPases (pumps), and $\mathrm{Ca}^{2+} /$ cation antiporters [2,3]. To maintain cellular $\mathrm{Ca}^{2+}$ homeostasis, these transporters have a pivotal role.

In horticultural crop production, enough $\mathrm{Ca}$ is generally supplied in the field. However, the occurrence of Ca deficiency disorders is observed in certain crops (e.g., tomato, lettuce, and Chinese cabbage) and causes serious economic losses [4-6]. It is suggested that $\mathrm{Ca}$ deficiency disorders are caused by the inability of the plant to translocate adequate $\mathrm{Ca}$ to the symptomatic organs, not the inability to acquire enough $\mathrm{Ca}$ [7-9]. In lisianthus (Eustoma grandiflorum (Raf.) Shinn.) cultivars, occurrence of tipburn (Ca deficiency disorder in the tips of new leaves) is a major problem in their production. Lisianthus is native to warm regions of the Southern United States and Northern Mexico. Its cultivars are mainly supplied as cut flowers. Previous research on occurrence of tipburn in lisinathus has suggested that differences in tipburn incidence and severity among the cultivars is af- 
fected little by $\mathrm{Ca}$ acquisition, plant growth rate, and transpiration rate $[10,11]$. In contrast, excessive $\mathrm{Ca}$ accumulation in roots under a high Ca supply was observed in tipburndamaged cultivars $[12,13]$. Moreover, cultivars in which tipburn occurred had increased Ca distribution to the roots before and after the onset of tipburn, and inhibited Ca distribution to the leaves [11]. Thus, it is clear that Ca accumulation in the root is a key factor in the incidence of tipburn in lisianthus cultivars. As far as we know, the clear phenotypic response (i.e., excessive $\mathrm{Ca}$ accumulation in roots) was not observed in other crops although several studies have been conducted to find the causative genes of tipburn using transcriptome analysis and QTL analysis [14-16]. Therefore, the search for candidate genes causing the excessive $\mathrm{Ca}$ accumulation in roots of tipburn-damaged lisianthus cultivars must provide new insights to identify the causative genes of tipburn.

In plant physiology, the relevance of cellular $\mathrm{Ca}^{2+}$ accumulation and the three classes of transporters has been investigated. Conn et al. [17] revealed that $C A X 1\left(\mathrm{Ca}^{2+} / \mathrm{H}^{+}\right.$ antiporter), $A C A 4$, and $A C A 11$ ( $\mathrm{Ca}^{2+}$-ATPases) were preferentially expressed in the Carich mesophyll of Arabidopsis thaliana leaves. Further, their analysis of loss-of-function mutants demonstrated that $C A X 1$ is a key regulator of the concentration of $\mathrm{Ca}^{2+}$ in the apoplast (apoplastic $\left[\mathrm{Ca}^{2+}\right]$ ) through compartmentalization of $\mathrm{Ca}^{2+}$ into mesophyll vacuoles. Transgenic tomatoes $[18,19]$ and potatoes $[20,21]$, expressing $s C A X 1$ from $A$. thaliana, increased total $\mathrm{Ca}$ content and caused a Ca deficiency disorder because they accumulated $\mathrm{Ca}^{2+}$ in vacuoles and their apoplastic $\left[\mathrm{Ca}^{2+}\right]$ reduced.

As well as vacuoles, the plant cell wall is also a big pool of $\mathrm{Ca}^{2+}$ in plant tissue. $\mathrm{Ca}^{2+}$ in the cell wall has a structural role, crosslinking with the homogalacturonan (HG) domain of pectin. Pectin methylesterases (PMEs) are key factors regulating the binding of the HG domain to $\mathrm{Ca}^{2+}$. PMEs dimethyl esterify certain glycan regions within the HG domain, enabling $\mathrm{Ca}^{2+}$ crosslink formation [22]. PME-silenced tomatoes exhibited lower blossom-end rot (Ca deficiency in fruit) incidence and higher apoplastic $\left[\mathrm{Ca}^{2+}\right]$ than those of wild-type [23]. Therefore, excessive Ca accumulation in tipburn-damaged lisianthus cultivars may be caused by the overexpression of genes encoding the three classes of transporters and PMEs.

In this study, RNA-seq of upper leaves and roots in lisianthus cultivars in which tipburn either occurs or does not, was conducted to determine the expression of genes encoding the three main Ca channels: voltage-dependent calcium channel protein (TPC1), glutamate receptors (GLRs), and cyclic nucleotide-gated ion channels (CNGCs) [24,25], two $\mathrm{Ca}^{2+}$-ATPases (P-IIA ER-type $\mathrm{Ca}^{2+}$-ATPases (ECAs) and P-IIB autoinhibited $\mathrm{Ca}^{2+}$ ATPases (ACAs)) [26], $\mathrm{Ca}^{2+} /$ cation antiporters (CaCA superfamily, including $\mathrm{Ca}^{2+} / \mathrm{H}^{+}$ antiporter (CAXs), $\mathrm{Na}^{+} / \mathrm{Ca}^{2+}$ exchanger-like proteins (NCLs), and cation $/ \mathrm{Ca}^{2+}$ exchangers (CCXs)) $[27,28]$, and PMEs. RNA-seq (de novo assembly) can be performed without a reference genome. Thus, it is suitable for studying non-model plants including lisianthus [29,30]. To provide a list of candidate target genes that might be causing the excessive $\mathrm{Ca}$ accumulation in roots, we analyzed the global differential gene expression of tipburn-occurrence and non-occurrence in each organ of cultivars.

\section{Materials and Methods}

\subsection{Plant Materials}

"Voyage peach" (VP) (Sakata Seed Corporation, Yokohama, Japan) and "Umi honoka" (UH) (Sumika Agrotech Co., Ltd., Osaka, Japan) cultivars were selected as a tipburndamaged cultivar and a tipburn-absent cultivar, respectively [13]. Before the onset of tipburn, VP exhibited a higher Ca concentration in each organ (whole leaves, stems, and roots) than was seen in UH (Table 1). After the onset of tipburn, whole leaf Ca concentrations in VP were lower than those of UH although VP had more than twice the Ca accumulation in the roots than $\mathrm{UH}$ (Table 1). Please see a previous study for more detail [13]. 
Table 1. Ca concentrations in each organ, tipburn incidence and severity of tipburn-absent cultivar (UH) and tipburndamaged cultivar (VP) at weeks 4 and 8 cited from a previous study [13].

\begin{tabular}{|c|c|c|c|c|c|c|c|c|c|c|c|c|c|c|c|}
\hline \multirow{4}{*}{ Cultivars } & \multirow{4}{*}{$\begin{array}{c}\text { Ca } \\
\text { Treatments } \\
40 \mathrm{ppm}\end{array}$} & \multicolumn{12}{|c|}{ Ca Concentrations of Each Organ (mg-Ca/kg-DW) } & \multirow{2}{*}{\multicolumn{2}{|c|}{$\begin{array}{c}\text { Tipburn } \\
(\% ; \text { Values at } 8 \mathrm{w})\end{array}$}} \\
\hline & & \multicolumn{6}{|c|}{$4 \mathrm{w}$ (before the Onset of Tipburn) } & \multicolumn{6}{|c|}{$8 \mathrm{w}$ (after the Onset of Tipburn) } & & \\
\hline & & \multicolumn{2}{|c|}{ Leaves } & \multicolumn{2}{|c|}{ Stems } & \multicolumn{2}{|c|}{ Roots } & \multicolumn{2}{|c|}{ Leaves } & \multicolumn{2}{|c|}{ Stems } & \multicolumn{2}{|c|}{ Roots } & \multirow{2}{*}{$\begin{array}{c}\text { Incidence } \\
0\end{array}$} & \multirow{2}{*}{$\frac{\text { Severity }}{0}$} \\
\hline & & 2.2 & & 1.1 & & 3.9 & & 3.3 & a & 1.2 & a & 4.0 & & & \\
\hline \multirow[t]{3}{*}{$\mathrm{UH}$} & 80 ppm & 2.2 & n.s. & 1.0 & n.s. & 3.9 & n.s. & 4.7 & $\mathrm{~b}$ & 1.6 & $\mathrm{~b}$ & 4.5 & n.s. & 0 & 0 \\
\hline & $120 \mathrm{ppm}$ & 2.3 & & 1.2 & & 3.7 & & 5.1 & c & 2.0 & c & 4.5 & & 0 & 0 \\
\hline & $40 \mathrm{ppm}$ & 3.1 & & 2.2 & & 6.0 & & 2.4 & $\mathrm{a}$ & 1.1 & $\mathrm{a}$ & 9.1 & a & 100 & 25 \\
\hline \multirow{2}{*}{ VP } & 80 ppm & 3.3 & n.s. & 2.7 & n.s. & 6.1 & n.s. & 3.3 & $\mathrm{~b}$ & 1.6 & $\mathrm{~b}$ & 11.6 & a & 100 & 16 \\
\hline & $120 \mathrm{ppm}$ & 3.3 & & 2.7 & & 6.9 & & 4.5 & c & 2.0 & c & 14.9 & $b$ & 100 & 12 \\
\hline
\end{tabular}

For the Ca concentrations of each organ, ANOVA was conducted to assess the effects of the treatment in each cultivar and significant differences among the means are indicated with different letters. n.s. represents no significant differences among the treatments. Cultivars: Umi honoka (UH) and Voyage peach (VP).

Seedlings were grown in the same way as in previous studies [10-13]. After plugs were transplanted into $0.25 \mathrm{~L}$ polyethylene pots, plants were supplied with a nutrient solution by bottom watering for $30 \mathrm{~min}$ once a day. The nutrient solution contained a $80 \mathrm{ppm}$ Ca concentration, which was made by dissolving nutrient salts in distilled water $0.202 \mathrm{~g} / \mathrm{L} \mathrm{KNO}_{3}$ (Fujifilm Wako Chemicals U.S.A. Corporation, Richmond, VA, USA), $0.236 \mathrm{~g} / \mathrm{LCa}\left(\mathrm{NO}_{3}\right)_{2} \cdot 4 \mathrm{H}_{2} \mathrm{O}$ (Fujifilm Wako Chemicals U.S.A. Corporation), $0.038 \mathrm{~g} / \mathrm{L} \mathrm{NH}_{4} \mathrm{H}_{2} \mathrm{PO}_{4}$ (Fujifilm Wako Chemicals U.S.A. Corporation), $0.123 \mathrm{~g} / \mathrm{L} \mathrm{MgSO}_{4} \cdot 7 \mathrm{H}_{2} \mathrm{O}$ (Fujifilm Wako Chemicals U.S.A. Corporation), $0.147 \mathrm{~g} / \mathrm{L} \mathrm{CaCl}_{2}$ (Fujifilm Wako Chemicals U.S.A. Corporation), and $0.4 \mathrm{~mL} / \mathrm{L}$ Otsuka-house No.5 L (OAT Agrio Co., Ltd., Tokyo, Japan) [12,13].

Five weeks later, three tipburn-absent pots were randomly sampled from each cultivar. Harvested plants were washed with distilled water and divided into roots and top leaves for total RNA extraction.

\subsection{RNA Extraction and RNA-Seq}

For the three biological replications of leaves and roots in each cultivar, total RNA was extracted using NucleoSpin ${ }^{\circledR}$ RNA Plant (Takara Bio Inc., Shiga, Japan). Contaminant DNA was eliminated using DNase and a quality check of RNA was conducted by Agilient Technologies 2100 Bioanalyzer (Agilent Technologies, Inc., Santa Clara, CA, USA). RNA Integrity Number (RIN) of all samples was greater than 8.0 and passed quality checks. TruSeq Stranded mRNA LT Sample Prep Kit (Illumina, Inc., San Diego, CA, USA) was used for library preparation. The 12 libraries were sequenced using the NovaSeq 6000 (Illumina, Inc., San Diego, CA, USA). The read data were submitted to the DDBJ Read Archive (BioProject: PRJDB10656, BioSample: SAMD00252781-SAMD00252792).

\subsection{Bioinformatics Analysis}

Low reads, adaptor sequences, contaminant DNA, and PCR duplicates were removed from raw reads to reduce bias in the analysis. The clean reads were assembled de novo using Trinity with default parameters. For assembled genes, the longest contigs were filtered and clustered into the non-redundant transcripts using the CD-HIT-EST program. These transcripts were defined as "unigenes" and aligned to the assembled reference using Bowtie program. The assembled unigenes were annotated using BLASTX of DIAMOND with an E-value cut-off $1.0 \times 10^{-5}$ in the gene ontology (GO) and UniProt databases.

For the top leaves and roots, differentially expressed genes (DEGs) were contrasted within each cultivar (VP (tipburn-damaged cultivar) vs. UH (tipburn-absent cultivar)) using a threshold of $p<0.05$. MA plots were drawn using DESeq2. For the target genes in this study, DEG lists, including genes with had $\log _{2}$ fold-change values $\left(\log _{2}\right.$ FC) higher than 2 (upregulated genes) and less than -2 (downregulated genes), were created. 


\section{Results}

\subsection{De Novo Transcriptome Assembly}

A total of 234,725 transcripts and 160,301 genes were assembled from 12 cDNA libraries using clean reads (Table 2). Average contig length was $750.74 \mathrm{bp}$.

Table 2. De novo transcriptome assembly statistics of upper leaves and roots in a tipburn damaged cultivar and a cultivar where tipburn did not occur.

\begin{tabular}{cc}
\hline Description & Assembly Statics * \\
\hline Total assembled bases & $176,216,995$ \\
Total number of assembled transcripts by Trinity & 234,725 \\
Total number of assembled genes by Trinity & 160,301 \\
Contig N50 & 1282 \\
Average contig length (bp) & 750.74 \\
GC (\%) & 40.64 \\
\hline * The values which total 12 libraries (two cultivars, two organs, and three biological replications) were assembled.
\end{tabular}

All Q30 levels of each cultivar were higher than 96\% (Table S1). Mapping ratios in each cultivar, obtained after aligning to the assembled reference were higher than $55 \%$ (Table S1).

\subsection{Functional Annotation}

For functional annotation of unigenes, the gene ontology (GO) database was applied to classify the annotated unigenes using BLASTX of DIAMOND with an E-value cut-off $1.0 \times 10^{-5}$ (Figure S1). In the biological process category, the largest group was "metabolic process $(35.04 \%)$ " (Figure S1). In the cellular component category, the largest number of genes was mapped to the term "call part (46.92\%)" (Figure S1). In the molecular function category, "catalytic activity $(46.47 \%)$ " was the largest group (Figure S1).

To determine the expression of genes encoding the Ca channels (TPC1, GLRs, and CNGCs), $\mathrm{Ca}^{2+}$-ATPases (ECAs and ACAs), $\mathrm{Ca}^{2+} /$ cation antiporters (CAXs, NCLs, and CCXs), and PMEs, we carried out BLASTX of DIAMOND with an E-value cut-off $1.0 \times 10^{-5}$ on UniProt database. The results for all cultivars and organs are summarized in Table S2. For the Ca channels, TPC1 was not detected while both GLRs and CNGCs were annotated with 13 genes (Table S2). For the $\mathrm{Ca}^{2+}$-ATPases, four ECAs and six ACAs were annotated (Table S2). For the $\mathrm{Ca}^{2+}$ / cation antiporters, four CAXs, two NCLs, and three CCXs were annotated (Table S2). PMEs were annotated with 35 genes (Table S2).

\subsection{Differentially Expressed Genes (DEGs)}

For each organ, DEGs were contrasted between cultivars (VP (tipburn-damaged cultivar) vs. UH (tipburn-absent cultivar)) using the $p$-value threshold of $<0.05$. MA plots were drawn using DESeq2 (Figure 1). In the upper leaves, 2240 contigs were upregulated and 1730 were downregulated in VP (the tipburn-damaged cultivar). In the roots, 1703 contigs were upregulated and 1673 were downregulated in VP.

For the genes encoding the Ca channels (13 GLRs, and 13 CNGCs), $\mathrm{Ca}^{2+}$-ATPases (four ECAs and six ACAs), $\mathrm{Ca}^{2+}$ /cation antiporters (four CAXs, two NCLs, and three CCXs), and 35 PMEs, upregulated and downregulated genes in upper leaves of VP are shown in Table 3. Three GLRs, two ACAs, CCX4, NCL, five PMEs were upregulated in VP while only three genes (GLR3.5, CNGC9, PME22) were downregulated. Upregulated and downregulated genes in roots of VP are shown in Table 4. GLR3.3, CAX5, CCX4, NCL, and five PMEs were upregulated in VP while only CNGC9 and ACA12 were downregulated. 

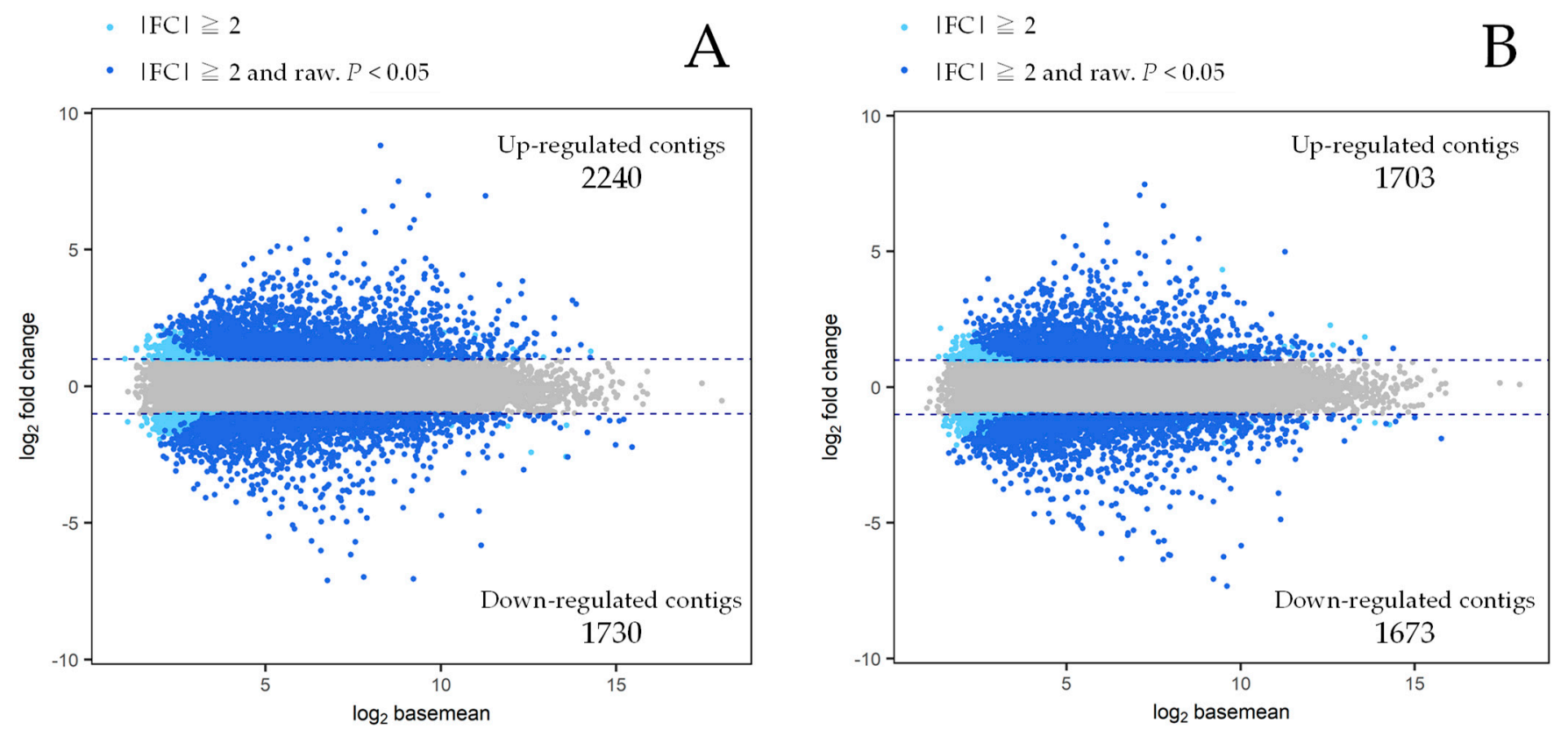

Figure 1. MA plots between VP (tipburn-damaged cultivar) vs. UH (tipburn-absent cultivar) in upper leaves (A) and roots (B). $X$-axis represents mean of normalized counts of each contig. $Y$-axis represents $\log _{2}$ fold-change of each contig. Upregulated and downregulated contigs were defined as $\log _{2}$ fold-change values $\left(\log _{2}\right.$ FC) higher than 2 and less than -2 with $p<0.05$, respectively.

Table 3. Upregulated and downregulated genes between a tipburn-damaged cultivar (VP) and a tipburn-absent cultivar (UH) in the upper leaves.

\begin{tabular}{|c|c|c|c|c|}
\hline Contig ID & Uniprot ID & Functional Annotation-Gene & Putative Localization & $\begin{array}{c}\log _{2} F C \\
\text { VP vs. UH }\end{array}$ \\
\hline c133995_g1_i7 & Q9SHV1 & GLR2.2 & plasma membrane & 6.03 \\
\hline c133636_g2_i4 & Q8LGN0 & GLR2.7 & membrane & 4.21 \\
\hline c130483_g1_i5 & Q9C8E7 & GLR3.3 & plasma membrane & 5.92 \\
\hline c123516_g1_i2 & Q9SW97 & GLR3.5 & plasma membrane & -2.15 \\
\hline c132090_g1_i2 & Q9M0A4 & CNGC9 & plasma membrane & -4.35 \\
\hline c133601_g3_i1 & Q37145 & $A C A 1$ & chloroplast inner membrane & 2.29 \\
\hline c133341_g1_i1 & Q9LY77 & ACA12 & membrane & 4.28 \\
\hline c134561_g2_i1 & Q9SYG9 & CCX4 & membrane & 3.19 \\
\hline c132676_g3_i2 & Q8L636 & $N C L$ & vacuole membrane, plasma membrane & 5.67 \\
\hline c131169_g3_i1 & Q43867 & PME1 & cell wall, golgi apparatus membrane & 2.07 \\
\hline c126734_g1_i1 & O48711 & PME12 & cell wall & 2.75 \\
\hline c130878_g3_i1 & Q9M9W7 & PME22 & cell wall & -2.35 \\
\hline c134669_g5_i2 & Q9M3B0 & PME34 & membrane & 16.36 \\
\hline c116073_g1_i1 & Q8VYZ3 & PME53 & cell wall & 3.09 \\
\hline c132368_g4_i1 & Q43062 & N/A (protein name: PE PPE8B) & cell wall & 2.73 \\
\hline
\end{tabular}


Table 4. Upregulated and downregulated genes between the tipburn-damaged cultivar (VP) and the tipburn-absent cultivar $(\mathrm{UH})$ in the roots.

\begin{tabular}{|c|c|c|c|c|}
\hline Contig ID & Uniprot ID & Functional Annotation-Gene & Putative Localization & $\begin{array}{c}\log _{2} \mathrm{FC} \\
\text { VP vs. UH }\end{array}$ \\
\hline c130483_g1_i5 & Q9C8E7 & GLR3.3 & plasma membrane & 10.85 \\
\hline c132090_g1_i2 & Q9M0A4 & CNGC9 & plasma membrane & -8.36 \\
\hline c133341_g1_i1 & Q9LY77 & $A C A 12$ & membrane & -2.68 \\
\hline c131257_g1_i2 & Q8L783 & CAX5 & vacuole membrane & 2.83 \\
\hline c134561_g2_i1 & Q9SYG9 & CCX4 & membrane & 3.13 \\
\hline c132676_g3_i2 & Q8L636 & $N C L$ & vacuole membrane, plasma membrane & 4.70 \\
\hline c113153_g1_i1 & Q9SIJ9 & PME11 & membrane & 3.63 \\
\hline c130878_g3_i1 & Q9M9W7 & PME22 & cell wall & 4.38 \\
\hline c123408_g2_i1 & O81301 & PME40 & cell wall & 2.40 \\
\hline c133846_g1_i1 & Q9FHN5 & PME59 & cell wall & 2.88 \\
\hline c132368_g4_i1 & Q43062 & N/A (protein name: PE PPE8B) & cell wall & 4.64 \\
\hline
\end{tabular}

\section{Discussion}

Before the onset of tipburn ( $4 \mathrm{w}$ after the start of the experiment), VP exhibited higher Ca concentrations in each organ (whole leaves, stems, and roots) than those of UH (Table 1) [13]. In contrast, after the onset of tipburn ( $8 \mathrm{w}$ after the start of the experiment), whole leaf $\mathrm{Ca}$ concentrations in VP were lower than those of UH although VP had more than twice the Ca accumulation in the roots than UH (Table 1) [13]. For each organ, DEGs were extracted as candidate genes related to excessive $\mathrm{Ca}$ accumulation just before the onset of tipburn ( $5 \mathrm{w}$ after the start of the experiment) (Tables 3 and 4). From these results, a hypothetical diagram of cellular Ca dynamics in each organ was drawn in Figure 2.

Upper leaf

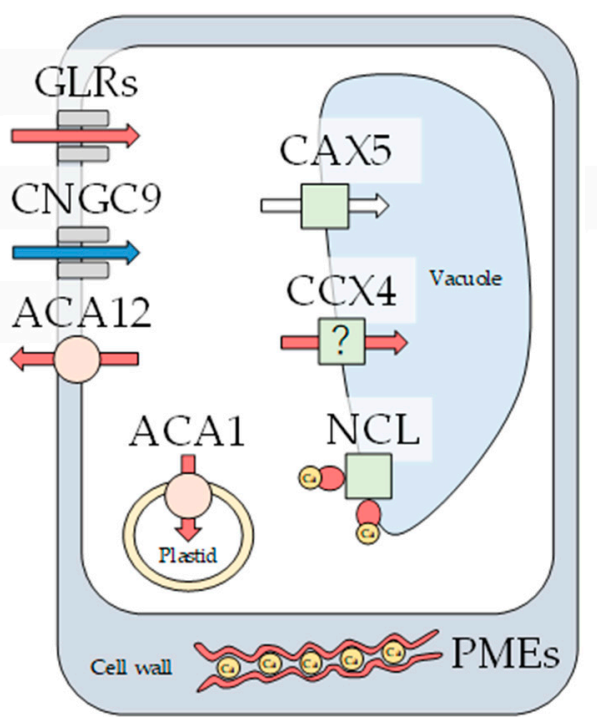

Root

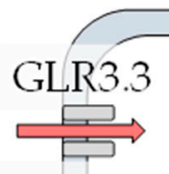

CNGC9

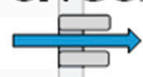

ACA12

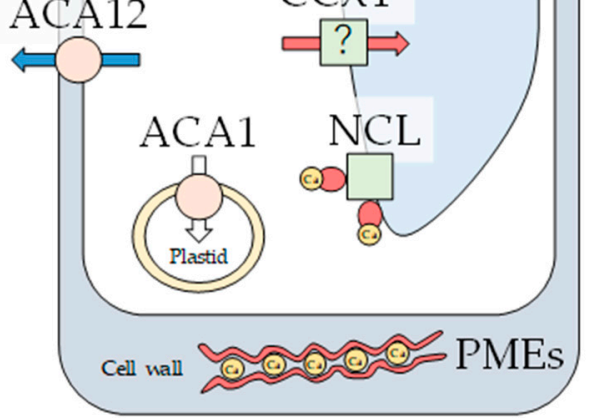

$\Xi$ Ca chamnels

$\bigcirc \mathrm{Ca}^{2+}$-ATPases

$\square \mathrm{Ca}^{2+} /$ cation antiporters

कora?

Crosslinked HG domain with $\mathrm{Ca}^{2+}$ by the activities of PMEs

$\Rightarrow \mathrm{Ca}^{2+}$ flux through the transporters encoding up-regulated genes in VP.

$\Rightarrow \mathrm{Ca}^{2+}$ flux through the transporters encoding down-regulated genes in V.

$\Longrightarrow \mathrm{Ca}^{2}+$ flux through the transporters encoding other than DEG.

EF-hand motifs in NCL $N C L$ was up-regulated in VP.

Figure 2. Hypothetical diagram of cellular Ca dynamics in upper leaves and roots of tipburn high damaged cultivar (VP). Direction of arrows indicates Ca flux through the transporters.

\subsection{Candidate Genes Causing the Difference of Ca Accumulation in Cultivars}

In both upper leaves and roots, GLRs, CCX4, NCL, and PMEs were upregulated and CNGC9 were downregulated in VP (Tables 3 and 4 and Figure 2). These are the suggested candidate genes causing the difference in $\mathrm{Ca}$ accumulation in the cultivars before the onset 
of tipburn (i.e., causing the higher Ca accumulation in each organ of VP rather than in $\mathrm{UH}$ $4 \mathrm{w}$ after the start of the experiment [13]).

Glutamate-gated receptors (GLRs) are known to act as non-selective cation channels and the Arabidopsis genome contains a family of 20 GLR genes. Qi et al. [31] revealed that GLR3.3 plays a role in $\mathrm{Ca}^{2+}$ influx channels at the plasma membrane, triggered directly or indirectly by six amino acids. In addition, Kim et al. [32] demonstrated that the overexpression of GLR3.2 leads to $\mathrm{Ca}^{2+}$ deficiency symptoms by impairing the efficiency of $\mathrm{Ca}^{2+}$ utilization. In the current study, most GLRs were upregulated in VP and more Ca accumulated than in UH. GLRs in lisianthus cultivars may have a relationship with Ca accumulation.

CCX4 has been identified as CAX10, but the results of the phylogenetic analysis showed that CCX4 is more closely related to the $\mathrm{K}^{+}$-dependent $\mathrm{Na}^{+} / \mathrm{Ca}^{2+}$ antiporter than to any of the CAXs. In addition, AtCCX4-expressing cells can suppress the $\mathrm{Na}^{+}$and $\mathrm{K}^{+}$sensitivities of mutant yeast strains defective in vacuolar $\mathrm{Na}^{+}$and $\mathrm{K}^{+}$transport [33]. However, Corso et al. [34] demonstrated that AtCCX2 plays a key role in controlling the $\mathrm{Ca}^{2+}$ fluxes between the endoplasmic reticulum (ER) and cytosol. Few functional analyses of CCX4 under high Ca concentrations have been conducted. Thus, effects of CCX4 expression on $\mathrm{Ca}$ accumulation in lisianthus should be investigated in more detail.

AtNCL $\left(\mathrm{Na}^{+} / \mathrm{Ca}^{2+}\right.$ exchanger-like protein) was identified as localizing in the Arabidopsis cell membrane fraction and plays an important role in $\mathrm{Ca}^{2+}$ homeostasis under salt stress conditions [35]. In addition, AtNCL has the EF-hand $\mathrm{Ca}^{2+}$ binding domain, and yeast cells expressing AtNCL accumulated more $\mathrm{Ca}^{2+}$ than the wild-type under $30 \mathrm{mM}$ $\mathrm{CaCl}_{2}$ [36]. In the current experiment, NCL may contribute to the accumulation of more $\mathrm{Ca}$ in VP because the nutrient solution in this experiment was dissolved in more $\mathrm{CaCl}_{2}$ and no $\mathrm{NaCl}$.

Based on the results of a previous study [23], more Ca accumulation in cell walls and a decrease in apoplastic $\left[\mathrm{Ca}^{2+}\right]$ may have occurred in the VP because many PMEs were upregulated in their upper leaves and roots.

Tan et al. [37] demonstrated that CNGC9 is a $\mathrm{Ca}^{2+}$-permeable channel essential for constitutive root hair growth in Arabidopsis. However, few studies have investigated the relevance of CNGC9 expression to Ca accumulation. Effects of CNGC9 expression on Ca accumulation in lisianthus also should be investigated in more detail.

\subsection{Candidate Genes Causing Excessive Ca Accumulation in Roots of VP}

In contrast to the abovementioned genes, $C A X 5, A C A 1, A C A 12$ showed different gene expression in each organ. $C A X 5$ expression was not significantly different among the cultivars in the upper leaves while it was upregulated in the roots of VP. CAX5 is the $\mathrm{Ca}^{2+}$ and $\mathrm{Mn}^{2+} / \mathrm{H}^{+}$antiporter in the vacuole and has autoinhibitory domains regulating $\mathrm{Ca}^{2+}$ transport activity [38]. In addition, AtCAX5-transformed yeast showed higher Ca concentrations in the intracellular matrix than the control group under the same exposure to an electromagnetic field (EMF) [39]. Accordingly, excessive Ca accumulation in the roots of VP may be caused by excessive Ca accumulation in the vacuole through the overexpression CAX5.

Expressions of $A C A 1$ in each organ were opposite to those of $C A X 5$ (in the upper leaves, $A C A 1$ was upregulated in VP; in roots, there was no significant difference in ACA1 expression among the cultivars). Huang et al. [40] demonstrated that ACA1 is a P-type $\mathrm{Ca}^{2+}$-ATPase localized in the inner plastid envelope of Arabidopsis. Its function is to maintain cytoplasmic $\mathrm{Ca}^{2+}$ at micromolar concentrations [2,17]. In roots, increments of $C A X 5$ expression and $\mathrm{Ca}$ accumulation in the vacuole may have resulted in decrements of $A C A 1$ expression and $\mathrm{Ca}$ influx to the plastid (Figure 2).

$A C A 12$ was upregulated in the upper leaves and downregulated in the roots of VP. ACA12 is localized in the plasma membrane and, unlike other ACAs, its activity is not stimulated by calmodulin [41]. Thus, ACA12 (calcium pump) activity is primarily regulated by increasing or decreasing mRNA expression [42]. 
Therefore, it is suggested that $C A X 5$ and $A C A 12$ are candidate genes causing the excessive $\mathrm{Ca}$ accumulation in roots of tipburn-damaged lisianthus cultivars. However, our experiment was only conducted just before the onset of tipburn ( $5 \mathrm{w}$ after the start of the experiment). In addition, the threshold of $p$-value $<0.05$ to be defined as DEGs may have been low (Figure 1). We need to comprehensively investigate the temporal changes in expression levels of annotated all genes (Table S2) using a quantitative PCR in the future. Functional analysis of candidate genes also should be conducted.

\section{Conclusions}

This study is the first attempt to provide a list of candidate target genes that might be causing the excessive $\mathrm{Ca}$ accumulation in roots of tipburn-damaged lisianthus cultivars. As a result, only two candidate genes were extracted. CAX5 was upregulated and ACA12 was downregulated in roots of a tipburn-damaged cultivar (VP). Therefore, tipburn-damaged cultivars may accumulate excessive $\mathrm{Ca}$ in the vacuole of roots through the overexpression of $C A X 5$, inhibiting the distribution of $C a$ to the upper leaves. Further research including functional analysis of these candidate genes should be conducted.

Supplementary Materials: The following are available online at https:/ / www.mdpi.com/2077-047 2/11/3/254/s1, Table S1: Total reads, Q30, and mapping ratios in each cultivar and organ, Table S2: Expression genes encoding the Ca channels (TPC1, GLRs, and CNGCs), $\mathrm{Ca}^{2+}$-ATPases (ECAs and ACAs), $\mathrm{Ca}^{2+}$ /cation antiporters (CAXs, NCLs, and CCXs), and PMEs in all cultivars and organs, Figure S1: Gene Ontology (GO) annotation of the assembled two lisianthus cultivars.

Author Contributions: Conceptualization, T.K. and H.W.; methodology, T.K.; validation, T.K. and H.W.; investigation, T.K.; resources, T.K. and H.W.; data curation, T.K.; writing-original draft preparation, T.K.; writing-review and editing, H.W.; visualization, T.K.; supervision, T.K.; project administration, T.K. and H.W.; funding acquisition, T.K. All authors have read and agreed to the published version of the manuscript.

Funding: This research was funded by JSPS KAKENHI, Grant Number JP19K15830.

Institutional Review Board Statement: Not applicable.

Informed Consent Statement: Not applicable.

Conflicts of Interest: The authors declare no conflict of interest.

\section{References}

1. White, P.J.; Broadley, M.R. Calcium in plants. Ann. Bot. 2003, 92, 487-511. [CrossRef]

2. Stael, S.; Wurzinger, B.; Mair, A.; Mehlmer, N.; Vothknecht, U.C.; Teige, M. Plant organellar calcium signalling: An emerging field. J. Exp. Bot. 2012, 63, 1525-1542. [CrossRef]

3. Costa, A.; Navazio, L.; Szabo, I. The contribution of organelles to plant intracellular calcium signalling. J. Exp. Bot. 2018, 69, 4175-4193. [CrossRef]

4. Hagassou, D.; Francia, E.; Ronga, D.; Buti, M. Blossom end-rot in tomato (Solanum lycopersicum L.): A multi-disciplinary overview of inducing factors and control strategies. Sci. Hortic. 2019, 249, 49-58. [CrossRef]

5. Sago, Y. Effects of light intensity and growth rate on tipburn development and leaf calcium concentration in butterhead lettuce. HortScience 2016, 51, 1087-1091. [CrossRef]

6. Hernandez, J.; Soriano, T.; Morales, M.I.; Castilla, N. Row covers for quality improvement of Chinese cabbage (Brassica rapa subsp. pekinensis). N. Z. J. Crop Hortic. Sci. 2004, 32, 379-388. [CrossRef]

7. Barta, D.J.; Tibbitts, T.W. Calcium localization and tipburn development in lettuce leaves during early enlargement. J. Am. Soc. Hortic. Sci. 2000, 125, 294-298. [CrossRef]

8. Kuo, C.G.; Tsay, J.S.; Tsai, C.L.; Chen, R.J. Tipburn of Chinese cabbage in relation to calcium nutrition and distribution. Sci. Hortic. 1981, 14, 131-138. [CrossRef]

9. Olle, M.; Bender, I. Causes and control of calcium deficiency disorders in vegetables: A review. J. Hortic. Sci. Biotrch. 2009, 84, 577-584. [CrossRef]

10. Kuronuma, T.; Watanabe, Y.; Ando, M.; Watanabe, H. Relevance of tipburn incidence to the competence for Ca acquirement and Ca distributivity in lisianthus [Eustoma grandiflorum (Raf.) Shinn.] cultivars. Sci. Hortic. 2019, 246, 805-811. [CrossRef]

11. Kuronuma, T.; Kinoshita, N.; Ando, M.; Watanabe, H. Difference of Ca distribution before and after the onset of tipburn in lisianthus [Eustoma grandiflorum (Raf.) Shinn.] cultivars. Sci. Hortic. 2020, 261. [CrossRef] 
12. Kuronuma, T.; Ando, M.; Watanabe, H. Tipburn Incidence and Ca acquisition and distribution in lisianthus (Eustoma grandiflorum (Raf.) Shinn.) cultivars under different Ca concentrations in nutrient solution. Agronomy 2020, 10, 216. [CrossRef]

13. Kuronuma, T.; Saotome, M.; Ando, M.; Watanabe, H. Excessive Calcium Accumulation in the Roots Is a Key Factor in Tipburn Incidence under High Ca Supply in Lisianthus (Eustoma grandiflorum) Cultivars. Agronomy 2020, 10, 1123. [CrossRef]

14. Lee, J.; Kim, J.; Choi, J.P.; Lee, M.; Kim, M.K.; Lee, Y.H.; Hur, Y.; Nou, S.; Park, S.U.; Min, S.R.; et al. Intracellular Ca ${ }^{2+}$ and K ${ }^{+}$ concentration in Brassica oleracea leaf induces differential expression of transporter and stress-related genes. BMC Genom. 2016, 17, 1-11. [CrossRef] [PubMed]

15. Su, T.; Li, P.; Wang, H.; Wang, W.; Zhao, X.; Yu, Y.; Zhang, D.; Yu, S.; Zhang, F. Natural variation in a calreticulin gene causes reduced resistance to $\mathrm{Ca}^{2+}$ deficiency-induced tipburn in Chinese cabbage (Brassica rapa ssp. pekinensis). Plant Cell Environ. 2019, 42, 3044-3060. [CrossRef]

16. Seki, K.; Komatsu, K.; Tanaka, K.; Hiraga, M.; Kajiya-Kanegae, H.; Matsumura, H.; Uno, Y. A CIN-like TCP transcription factor (LsTCP4) having retrotransposon insertion associates with a shift from Salinas type to Empire type in crisphead lettuce (Lactuca sativa L.). Hortic. Res. 2020, 7, 1-14. [CrossRef] [PubMed]

17. Conn, S.J.; Gilliham, M.; Athman, A.; Schreiber, A.W.; Baumann, U.; Moller, I.; Cheng, N.H.; Stancombe, M.A.; Hirschi, K.D.; Webb, A.A.R.; et al. Cell-specific vacuolar calcium storage mediated by $C A X 1$ regulates apoplastic calcium concentration, gas exchange, and plant productivity in Arabidopsis. Plant Cell 2011, 23, 240-257. [CrossRef] [PubMed]

18. Park, S.; Cheng, N.H.; Pittman, J.K.; Yoo, K.S.; Park, J.; Smith, R.H.; Hirschi, K.D. Increased calcium levels and prolonged shelf life in tomatoes expressing Arabidopsis $\mathrm{H}^{+} / \mathrm{Ca}^{2+}$ transporters. Plant Physiol. 2005, 139, 1194-1206. [CrossRef] [PubMed]

19. Freitas, S.T.; Padda, M.; Wu, Q.; Park, S.; Mitcham, E.J. Dynamic alternations in cellular and molecular components during blossom-end rot development in tomatoes expressing sCAX1, a constitutively active $\mathrm{Ca}^{2+} / \mathrm{H}^{+}$antiporter from Arabidopsis. Plant Physiol. 2011, 156, 844-855. [CrossRef]

20. Zorrilla, C.; Schabow, J.E.; Chernov, V.; Palta, J.P. CAX1 vacuolar antiporter overexpression in potato results in calcium deficiency in leaves and tubers by sequestering calcium as calcium oxalate. Crop Sci. 2019, 59, 176-189. [CrossRef]

21. Gao, H.; Wu, X.; Zorrilla, C.; Vega, S.E.; Palta, J.P. Fractionating of calcium in tuber and leaf tissues explains the calcium deficiency symptoms in potato plant overexpressing CAX1. Front. Plant Sci. 2020, 10, 1793. [CrossRef]

22. Wormit, A.; Usadel, B. The multifaceted role of pectin methylesterase inhibitors (PMEIs). Int. J. Mol. Sci. 2018, 19, 2878. [CrossRef]

23. Freitas, S.T.; Handa, A.K.; Wu, Q.; Park, S.; Mitcham, E.J. Role of pectin methylesterases in cellular calcium distribution and blossom-end rot development in tomato fruit. Plant J. 2012, 71, 824-835. [CrossRef] [PubMed]

24. Ward, J.M.; Mäser, P.; Schroeder, J.I. Plant ion channels: Gene families, physiology, and functional genomics analyses. Ann. Rev. Physiol. 2009, 71, 59-82. [CrossRef] [PubMed]

25. Swarbreck, S.M.; Colaço, R.; Davies, J.M. Plant calcium-permeable channels. Plant Physiol. 2013, 163, 514-522. [CrossRef] [PubMed]

26. García Bossi, J.; Kumar, K.; Barberini, M.L.; Domínguez, G.D.; Rondón Guerrero, Y.D.C.; Marino-Buslje, C.; Obertello, M.; Muschietti, J.P.; Estevez, J.M. The role of P-type IIA and P-type IIB Ca ${ }^{2+}$-ATPases in plant development and growth. J. Exp. Bot. 2020, 71, 1239-1248. [CrossRef] [PubMed]

27. Taneja, M.; Tyagi, S.; Sharma, S.; Upadhyay, S.K. Ca ${ }^{2+}$ / cation antiporters (CaCA): Identification, characterization and expression profiling in bread wheat (Triticum aestivum L.). Front. Plant Sci. 2016, 7, 1775. [CrossRef] [PubMed]

28. Amagaya, K.; Shibuya, T.; Nishiyama, M.; Kato, K.; Kanayama, Y. Characterization and Expression Analysis of the Ca ${ }^{2+} / \mathrm{Cation}^{2}$ Antiporter Gene Family in Tomatoes. Plants 2020, 9, 25. [CrossRef] [PubMed]

29. Wimberley, J.; Cahill, J. De novo Sequencing and Analysis of Salvia hispanica Tissue-Specific Transcriptome and Identification of Genes Involved in Terpenoid Biosynthesis. Plants 2020, 9, 405. [CrossRef]

30. Cechin, J.; Piasecki, C.; Benemann, D.P.; Kremer, F.S.; Galli, V.; Maia, L.C.; Agostinetto, D.; Vargas, L. Transcriptome Analysis Identifies Candidate Target Genes Involved in Glyphosate-Resistance Mechanism in Lolium multiflorum. Plants 2020, 9, 685. [CrossRef]

31. Qi, Z.; Stephens, N.R.; Spalding, E.P. Calcium entry mediated by GLR3.3, an Arabidopsis glutamate receptor with a broad agonist profile. Plant Physiol. 2006, 142, 963-971. [CrossRef] [PubMed]

32. Kim, S.A.; Kwak, J.; Jae, S.K.; Wang, M.H.; Nam, H. Overexpression of the AtGluR2 Gene Encoding an Arabidopsis Homolog of Mammalian Glutamate Receptors Impairs Calcium Utilization and Sensitivity to Ionic Stress in Transgenic Plants. Plant Cell Physiol. 2001, 42, 74-84. [CrossRef] [PubMed]

33. Morris, J.; Tian, H.; Park, S.; Sreevidya, C.S.; Ward, J.M.; Hirschi, K.D. AtCCX3 is an Arabidopsis endomembrane H+-dependent K+ transporter. Plant Physiol. 2008, 148, 1474-1486. [CrossRef] [PubMed]

34. Corso, M.; Doccula, F.G.; de Melo, J.R.F.; Costa, A.; Verbruggen, N. Endoplasmic reticulum-localized CCX2 is required for osmotolerance by regulating ER and cytosolic $\mathrm{Ca}^{2+}$ dynamics in Arabidopsis. Proc. Natl. Acad. Sci. USA 2018, 115, $3966-3971$. [CrossRef]

35. Wang, P.; Li, Z.; Wei, J.; Zhao, Z.; Sun, D.; Cui, S. A Na ${ }^{+} / \mathrm{Ca}^{2+}$ exchanger-like protein (AtNCL) involved in salt stress in Arabidopsis. J. Biol. Chem. 2012, 287, 44062-44070. [CrossRef] [PubMed]

36. Li, P.; Zhang, G.; Gonzales, N.; Guo, Y.; Hu, H.; Park, S.; Zhao, J. $\mathrm{Ca}^{2+}$-regulated and diurnal rhythm-regulated $\mathrm{Na}^{+} / \mathrm{Ca}^{2+}$ exchanger AtNCL affects flowering time and auxin signalling in Arabidopsis. Plant Cell Environ. 2016, 39, 377-392. [CrossRef] [PubMed] 
37. Tan, Y.Q.; Yang, Y.; Zhang, A.; Fei, C.F.; Gu, L.L.; Sun, S.J.; Xu, W.; Wang, L.; Liu, H.; Wang, Y.F. Three CNGC family members, CNGC5, CNGC6, and CNGC9, are required for constitutive growth of Arabidopsis root hairs as $\mathrm{Ca}^{2+}$-permeable channels. Plant Commun. 2020, 1, 100001. [CrossRef] [PubMed]

38. Edmond, C.; Shigaki, T.; Ewert, S.; Nelson, M.D.; Connorton, J.M.; Chalova, V.; Noordally, Z.; Pittman, J.K. Comparative analysis of CAX2-like cation transporters indicates functional and regulatory diversity. Biochem. J. 2009, 418, 145-154. [CrossRef]

39. Choe, M.; Choe, W.; Cha, S.; Lee, I. Changes of cationic transport in AtCAX5 transformant yeast by electromagnetic field environments. J. Biol. Phys. 2018, 44, 433-448. [CrossRef]

40. Huang, L.; Berkelman, T.; Franklin, A.E.; Hoffman, N.E. Characterization of a gene encoding a Ca ${ }^{2+}$-ATPase-like protein in the plastid envelope. Proc. Natl. Acad. Sci. USA 1993, 90, 10066-10070. [CrossRef]

41. Yu, H.; Yan, J.; Du, X.; Hua, J. Overlapping and differential roles of plasma membrane calcium ATPases in Arabidopsis growth and environmental responses. J. Exp. Bot. 2018, 69, 2693-2703. [CrossRef] [PubMed]

42. Limonta, M.; Romanowsky, S.; Olivari, C.; Bonza, M.C.; Luoni, L.; Rosenberg, A.; Harper, J.F.; De Michelis, M.I. ACA12 is a deregulated isoform of plasma membrane $\mathrm{Ca}^{2+}$-ATPase of Arabidopsis thaliana. Plant Mol. Biol. 2014, 84, 387-397. [CrossRef] [PubMed] 